\title{
Udfordringer med digital Multiple Choice Questions, som eksamensform på medicin studiet, Health, Aarhus Universitet
}

\section{Eivind Ortind}

\section{Simonsen}

Systemudvikler

Center for Medicinsk Uddannelse, Aarhus Universitet.

\section{Kristian Krogh}

Ph.d.-studerende, læge Center for Medicinsk Uddannelse, Aarhus Universitet.

\section{Mads R. Dahl}

Specialkonsulent

Center for Medicinsk Uddannelse, Aarhus Universitet.

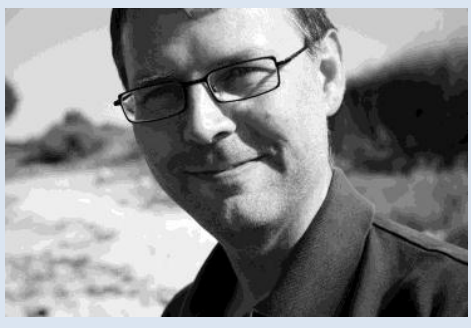




\section{Abstract (english)}

In this article we describe our experiences gained and lessons learnt from developing and using a digital system for MCQ exams at the Medical Education, Aarhus University, Denmark. The motivation from developing such a system stems from the problems experienced by the administration running such an exam. As a side effect the students will get the possibility of getting more interactive content in their future exams. Our focus of this paper is on the technical side, where the hardware and software issues related to this system are described. We do also touch upon issues related to the organizational side of running a digital exam. Our conclusion is that this system alleviates some part of the administrative problems and opens up for future possibilities in developing good MCQ exams.

\section{Abstract (danish)}

I denne artikel belyser vi de erfaring vi har opnået ved at udvikle og anvende et digitalt system til afholdelse af en MCQ-eksamen på Health ved Aarhus Universitet, Danmark. Den primære motivation for at udvikle sådan et system, kommer fra den administrative side, hvor der er knyttet nogle mindre problemer med afvikling af en MCQ-eksamen. Som en sidegevinst, vil de studerende kunne få muligheden for bedre materiale til deres fremtidige eksamener. Fokus er på den tekniske løsning, hvor hardware og software delen af systemet beskrives. Vi kommer også ind på de organisatoriske aspekter ved at afholde en digital eksamen. Vores konklusion er, at dette system afhjælper en del af de problemer, som administrationen har, og åbner op for fremtidige muligheder for at udvikle bedre MCQ-eksamener. 


\section{Indledning}

Videnskabsministeriet udgav i 2010 en rapport om digitale eksaminer på universiteterne (Bygningsstyrelsen, 2010), hvori udfordringer og anbefalinger vedrørende digitale eksamener ved danske universiteter blev belyst. Denne rapport kom som opfølgning på regeringens målsætning fra 2007 (III, 2007) om at:

"Al skriftlig kommunikation mellem studerende og
uddannelsesinstitutioner skal foregå elektronisk, og alle
studerende på videregående uddannelser skal have mulighed for
at aflevere skriftlige opgaver elektronisk."

Et fælles udspil fra regeringen, KL og danske regioner angående den fællesoffentlige digitaliseringsstrategi (Økonomistyrelsen, 2011) fastlægger, at:
"Derfor skal eksamensformerne udvikles og tilpasses den digitale tidsalder. Og den teknologiske infrastruktur skal opgraderes, så de skriftlige prøver senest i 2013 kan gennemføres uden brug af blyant og papir."

I nærværende artikel beskrives det, hvordan Faculty of Health på AU har forsøgt at leve op til dele af denne målsætning med udgangspunkt i en digital løsning til Multiple Choice Questions-eksamener (MCQ). Artiklen vil primært fokusere på de tekniske aspekter ved afholdelse af denne eksamen.

\section{MCQ-eksamen}

En MCQ-eksamen består af en række spørgsmål med et bestemt antal svarmuligheder (Lowe, 1991). Eksaminanden afkrydser den svarmulighed, som vedkommende mener er rigtig. Den endelige karakter afhænger af antal rigtige besvarelser. På Health består en MCQ-eksamen af 80 spørgsmål med tre svarmuligheder for hvert spørgsmål. Eksamen afvikles som en to timers stedprøve for at sikre sig, at det er den studerende selv, der besvarer opgaven.

\section{Non-digital MCQ-eksamen på Health}

For at afholde en MCQ-eksamen er det nødvendigt, at have to gange 80 spørgsmål, således at der kan afholdes en eksamen og en reeksamen. Enkelte spørgsmål eller ordlyd fra spørgsmål genanvendes fra tidligere eksamener, men de fleste spørgsmål skal være nye for at sikre en ensartet sværhedsgrad af eksamen fra år til år uden risiko for duplikation af tidligere eksamenssæt. Ansvaret for udarbejdelse af spørgsmål ligger hos de til faget knyttede lærestolsprofessorer. Den endelige godkendelse ligger hos den undervisningsansvarlige og tre censorer. Når spørgsmålene er 
godkendt bliver eksamenssættet sendt til trykkeri, hvor ca. 200 sæt trykkes per eksamen. Til reeksamen er der behov for betydeligt færre sæt. Til hvert eksamenssæt hører et svarark, hvor de studerende kan sætte kryds ud for det svar, de mener, er rigtigt. Når eksamen er slut indsamles disse svarark, som gennemgås og kontrolleres for at finde antal rigtige svar.

Gennemgangen af svarark foregår manuelt ved at lægge en transparent over hvert svarark. På denne transparent er svararket printet med de rigtige besvarelser afkrydset. Hvis der ud for et spørgsmål findes to krydser, har den studerende svaret forkert. Hvis svaret derimod overlapper, er besvarelsen korrekt. Denne gennemgang af svarark tager 12 timer og varetages af 6-8 kontrollanter. Hvert svarark bliver gennemgået mindst to gange for at sikre sig, at der er talt rigtigt sammen.

For at kvalitetssikre eksamen laves der en række statistikker på alle spørgsmål. Hvis et stort antal studerende har problemer med bestemte spørgsmål kunne dette være en indikation for, at der er noget galt med disse spørgsmål. For at afdække kvaliteten af spørgsmålene og til dels den forudgående undervisning, indtastes alle besvarelser i et regneark med henblik på statistiske beregninger. Indtastningen foregår manuelt og tager 1-2 arbejdsdage.

\section{Baggrund for digitalisering}

Der er en række administrative udfordring ved en manuel MCQ-eksamen. Især problemstillingen omkring forkert sammentælling af antal korrekte besvarelser efter eksamen er en kilde til bekymring. Forkert sammentælling viser sig i praksis ved, at der er uoverensstemmelse mellem første og anden gennemgang af svararkene. Disse svarark skal derfor gennemses endnu en gang. Således prøver man at sikre sig mod fejl uden dog at kunne sikre sig, at antal korrekte besvarelser vitterligt er rigtigt. Blot en enkelt fejl i sammentællingen kan bevirke et forkert eksamensresultat.

Udover usikkerheden ved resultatudregningen er ulemperne også, at 6-8 kontrollanter er nødt til at bruge tid på sammentællingen, ligesom tastefejl kan opstå ved indtastningen af data til statistik.

Alle disse problemstillinger elimineres ved en digitalisering af eksamen (Jalali et al., 2012). Når eksamen besvares digitalt findes alle besvarelser i en database. At finde det korrekte antal besvarelser bliver derfor kun et spørgsmål om en enkelt gang at programmere en funktion, som traverserer de studerendes besvarelser og holder disse op imod de korrekte besvarelser i databasen. Udførslen af funktionen tager 1-2 sekunder, hvilket står i skærende kontrast til de 1-2 timer en manuel gennemgang varer. En elektronisk gennemgang af besvarelser, lider heller ikke under risikoen for, at der bliver talt forkert sammen. De 6-8 kontrollanter, der er nødvendige ved manuel optælling, bliver ligeledes overflødig. 
At kvalitetssikre eksamen bliver også nemmere. Alle besvarelser findes i databasen så snart de studerende har afsluttet eksamen, hvilke igen overflødiggør manuel indtastning og den risiko det indebærer.

På sigt vil en digitalisering af eksamener give mulighed for at lave spørgsmål, hvor billeder af høj kvalitet og stor detaljegrad bliver en integreret del. Som det er nu, bliver disse billeder printet ud, og dermed går noget af kvaliteten tabt. Med en digital version af billedet er det desuden muligt at zoome ind og ud, samt at justere kontrast, hvorved den studerende vil have et bedre og mere reelt grundlag for at vurdere f.eks. et røntgenbillede, da tilsvarende muligheder bruges i det kliniske arbejde.

En digital eksamen åbner også op for at inddrage andre muligheder som eksempelvis videosekvenser af en ultralydsscanning og lydfiler af en hjerterytme, hvilke ikke er muligt med en papirbaseret eksamen.

For den studerende vil der også være mulighed for mere detaljeret feedback. Da alle oplysninger bliver gemt i systemet, vil den studerende kunne modtage oplysninger omkring de valg, som de har foretaget i løbet af eksamen. Især den kritiske periode op til eksamens afslutning, hvor mange studerende retter i tidligere besvarelser, vil nu kunne konkretiseres i form af statistiske udregninger. Kan det f.eks. betale sig at man fulgte sin første indskydelse, eller var det bedre at ændre besvarelser, man var i tvivl om? Med en papirbaseret version vil sådan en statistik være umulig, men med et digitalt system åbner muligheden sig for at give denne feedback til de studerende (Ellaway \& Masters, 2008).

Når eksamen er slut er der mulighed for, at den studerende kan modtage en bekræftelse på eksamensdeltagelse samt sin eksamensbesvarelse via elektronisk post. 


\section{MCQ-systemet}

Nedenfor belyses den tekniske løsning til de ovenfor nævnte problemstillinger. Foruden at lette den administrative byrde ved afholdelse af en MCQ-eksamen, så er systemet tænkt med mobilitet som omdrejningspunkt, da eksamen afholdes på forskellige lokalisationer fra gang til gang og skal kunne dække mellem 20 og 200 studerende samtidig eventuelt på flere matrikler afhængig af lokaletilgængeligheden. Systemet er en selvkørende enhed, som kun har behov for at blive tilsluttet strøm. Når eksamen skal afholdes, fragtes systemet ud på lokaliteten, det sættes op og eksamens afvikles. Systemet har sit eget netværk og er dermed ikke begrænset af at skulle anvende et allerede eksisterende netværk. Den trafik, der er på systemets trådløse netværk er udelukkende knyttet til afvikling af eksamen.

Begrundelsen for overhovedet at lave et MCQ-system fra bunden af skal ses i lyset af især tre faktorer:

1. Det e-læringssystem, som Aarhus Universitet anvender (AULA), står på tærskelen til at blive udskiftet. Hvis vi valgte at lave systemet $\mathrm{i}$ AULA, så ville denne løsning højst kunne anvendes få gange, før der skal laves noget nyt igen.

2. Udviklingen af MCQ-systemet skal ses som en slags forløber for den fremtidige udvikling af et digitalt system til en OSKE (Objektiv Struktureret Klinisk Eksamen). Det er vores skøn, at det blot er et spørgsmål om tid, inden denne eksamen sættes i gang på AU, og til den tid vil der være opbygget erfaringer ved udviklingen og anvendelsen af MCQ-systemet. Det forventes at tilpasningen af et system til MCQeksamener til et system til afholdelse af en OSKE kan foretages forholdsvis problemfrit.

3. Der ønskes uafhængighed af adgang til internettet. Primært på grund af sikkerheden, men også fordi det vurderes, at denne adgang ofte har voldt problemer for diverse online prøver afholdt andre steder i Danmark.

\section{Planlagt Objektiv Struktureret Klinisk Eksamen}

Den oprindelige målsætning var, at afholde en Objektiv Struktureret Klinisk Eksamen (OSKE) ("OSCEhome Cinical Skills Assessment Medical OSCE Exam Objective Structured Clinical Examination," 2012). Tanken var, at denne eksamen skulle være digital i modsætning til mange andre steder, hvor den bliver udført på papir. Denne eksamensform kræver meget forberedelse og personale, hvorfor det blev fra administrationens side skønnet, at det var hensigtsmæssigt at vente med at lave en så radikal ændring $\mathrm{i}$ 
eksamensformen. I stedet for en OSKE blev det valgt at gennemføre en MCQ-eksamen.

Da beslutningen om at aflyse OSKE blev taget, var forberedelserne til denne eksamen allerede meget fremskredne, ligesom analyserne af en mulig teknisk løsning var foretaget. Det var derfor naturligt for os at inkorporere vores løsningsmodel til en OSKE i vores overvejelser omkring en MCQeksamen. Bedømmelsen af den studerende i begge eksamensformer består af at sammentælle de afkrydsninger, der er foretaget i løbet af eksamen. Forskellen er, hvem der foretager denne afkrydsning: til OSKE er det eksaminator, til MCQ-eksamen er det den studerende selv. Denne forskel har dog ikke nævneværdig betydning for selve systemet, da det er de indtastede data, der er af interesse, og ikke hvem, der foretager indtastningen.

\section{Hardware}

Selve hardware-delen af systemet var på plads inden udviklingen af programmet. Som nævnt ovenfor var forberedelserne til OSKE meget fremskredne, hvilke inkluderede indkøb af hardware. Til den planlagte OSKE var der planlagt, at der skulle være 20 stande tre forskellige steder, således at der i alt ville være 60 stande. Hver stand skulle have en teknisk enhed, hvor alle oplysninger omkring eksamensforløbet for den enkelte studerende skulle noteres. Derfor skulle der som minimum være 60 individuelle tekniske enheder for at opfylde de hardwaremæssige krav til afholdelse af en OSKE på Aarhus Universitet.

Det blev skønnet, at en tabletløsning ville være bedst, da en tablet er en fysisk mindre enhed end en bærbar computer, og det derfor ville det være nemmere for eksaminator at bevæge sig rundt i lokalet under eksaminationen (Jones \& Sinclair, 2011). Denne form for mobilitet forudsætter, at batteri-levetiden på enheden er god, da en OSKE kan forventes at vare en hel arbejdsdag.

Diverse tabletbaserede løsninger (Attewell, 2005; Herrmann, 2012; Hwang \& Chang, 2011; Jalali et al., 2012) blev overvejet, men valget blev Apples iPads, da disse lever fuldt op til kravet vedrørende batteri-levetid samt mobilitet. Erfaringer med Apples routere og trådløse netværk spillede også rolle for dette valg. Ved at basere hele systemet på produkter fra én producent vil der opstå en slags teknisk synergieffekt, da disse produkter ofte er fremstillet efter samme specifikationskrav og dermed kan forventes at samarbejde mere gnidningsløst. Servere blev derfor ligeledes baseret på en Apple-løsning, sådan at hele hardware-siden af systemet blev baseret på Apples produkter.

Disse overvejelser blev, som nævnt, foretaget i forbindelse med vores OSKE-eksamen (McNulty \& Chandrasekhar, 2011; Wang, 2008). For at 
dække behovet til en OSKE var det nødvendigt med minimum 60 iPads og med nogle enkelte iPads som backup, blev der i alt indkøbt 78. Desuden blev der indkøbt 7 Mac Mini (desktop-computer), der fungerer som server, samt 7 Airport Extreme Base Stations, som kunne levere vores netværk. Derudover blev der anskaffet 12 Airport Express Base Stations, som var tænkt til at forlænge signalet fra netværket.

For at fragte systemet rundt blev der anskaffet tre trolleys, som kan oplade og synkronisere op til 32 iPads ad gangen.

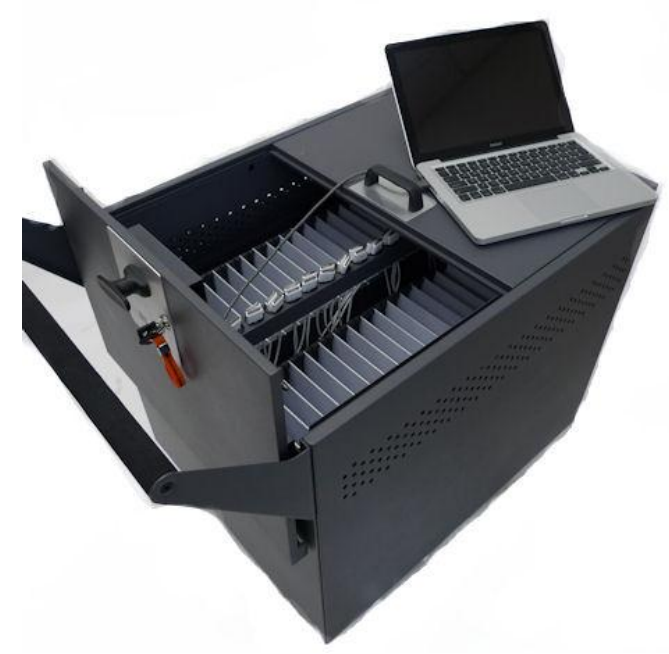

Figur 1. Mini iPad cart fra Datamation Systems INC til transport og opbevaring af hardware.

\section{Software}

Valget af en Apple-baseret hardwareløsning medførte, at den software som skulle udvikles, skulle køre på Apples operativsystem til trådløse enheder iOS. Software til iOS-baserede enheder bygger primært på programmeringssproget Objective-C, der anvendes til at lave de velkendte Apps, som man kan rekvirere i App Store på en iOS-baseret enhed.

Denne mulighed blev fravalgt, da det ikke var ønskværdigt at låse systemet til specifik hardware. Med en App-løsning ville systemet kun kunne afvikles på et iOS-system, og det skønnes ikke at være hensigtsmæssigt i forhold til fremtidige muligheder, hvor der gerne skulle være mulighed for valgfrihed angående hardware (Mowla, Zaman, Chowdhury, \& Abdal, 2007).

Derfor blev der taget en beslutning om, at softwaredelen af vores system skulle være så generel som muligt. Ud fra devisen "less is more" er systemet i al sin enkelthed bygget op som en almindelig hjemmeside, hvor de studerende logger ind og får præsenteret et eksemplar af deres MCQeksamen (Wang, 2008). Denne eksamen kan de besvare på selve 
hjemmesiden, og alle besvarelser samt ændringer i besvarelserne bliver gemt i en database. Databasen er lavet i MySQL (MySQL, 2012) og selve hjemmesiden er udviklet i PHP (PHP, 2012). Sammen med en Apachewebserver (MAMP, 2012) udgør disse tre teknologier en hjemmesideløsning, som er meget anvendt på verdensplan. Dette var én af grundene til, at denne løsning blev valgt. Alle tre teknologier fås i en samlet pakke, som kan installeres på de mest gængse operativsystemer - i dette tilfælde operativsystemet MacOS. Den samlede pakke kan downloades gratis fra internettet (Welcome to The Apache Software Foundation!, 2012).

Den studerende logger ind ved at indtaste sit eksamensnummer eller studienummer samt det password, der bliver genereret til hver enkelt studerende. Efter login bliver den studerende præsenteret for en statusside, hvor deres eksamens- og studienummer står anført sammen med deres navn samt oplysninger om, hvilken eksamen de er i gang med at tage. Der er også et link til selve eksamen, som det dog ikke er aktivt før eksamen går i gang.

Når eksamen starter, bliver linket aktiveret af en administrator. De studerende kan nu klikke på linket og det fører dem til det første spørgsmål i eksamenssættet. Spørgsmålene bliver præsenteret øverst på siden, og de tre svarmuligheder står i højre side (Vyas \& Supe, 2008).

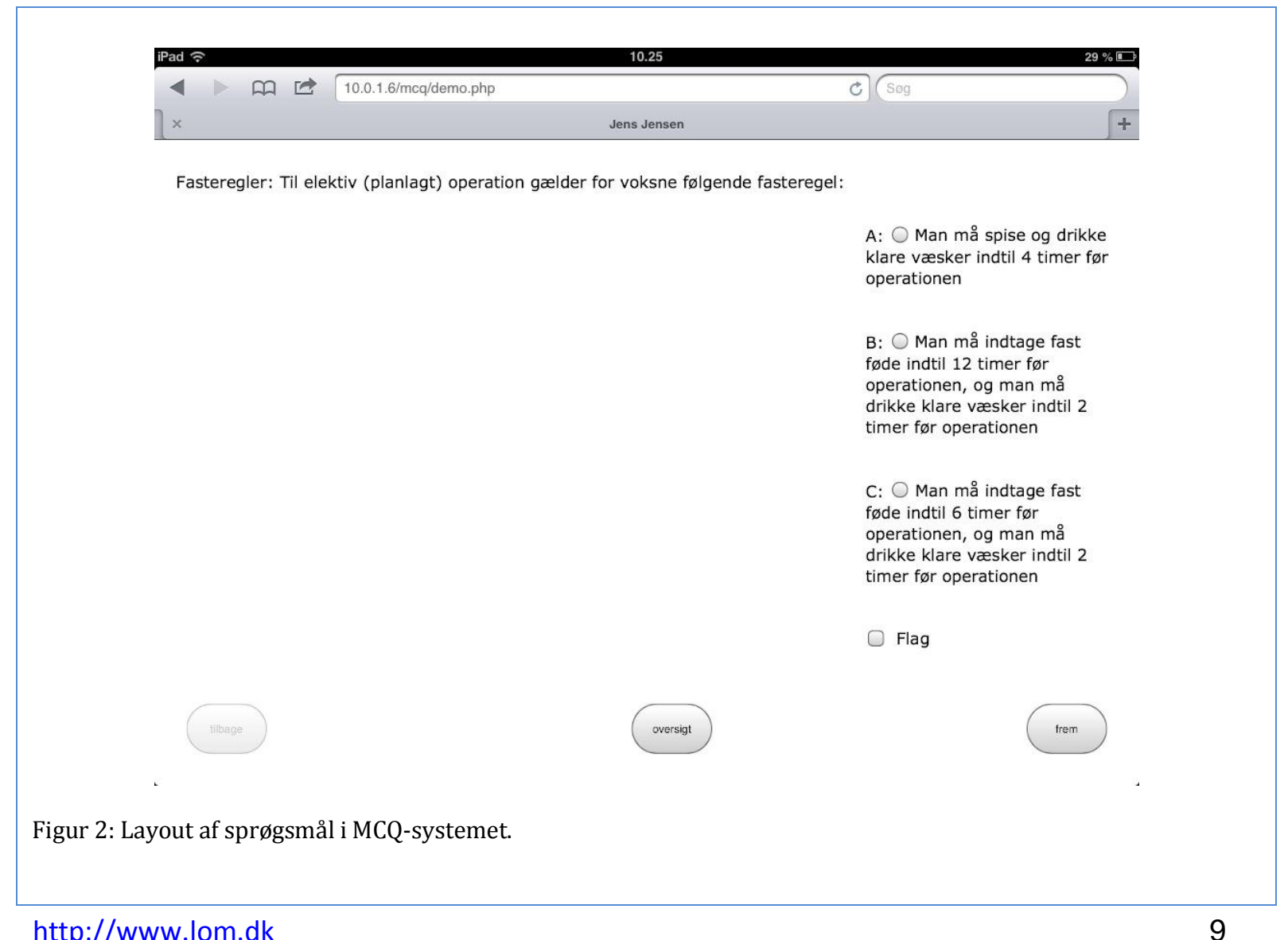


Nederst på siden er der tre knapper. To af dem er til navigation frem og tilbage i eksamenssættet, mens den tredje er til en oversigtsside over alle spørgsmålene, hvor den studerende kan få overblik over, hvilke spørgsmål, der mangler at besvares. Der er også muligt for de studerende at markere de spørgsmål, som de måtte være i tvivl om. Denne markering vil fremgå ved en rød fane på oversigtssiden.

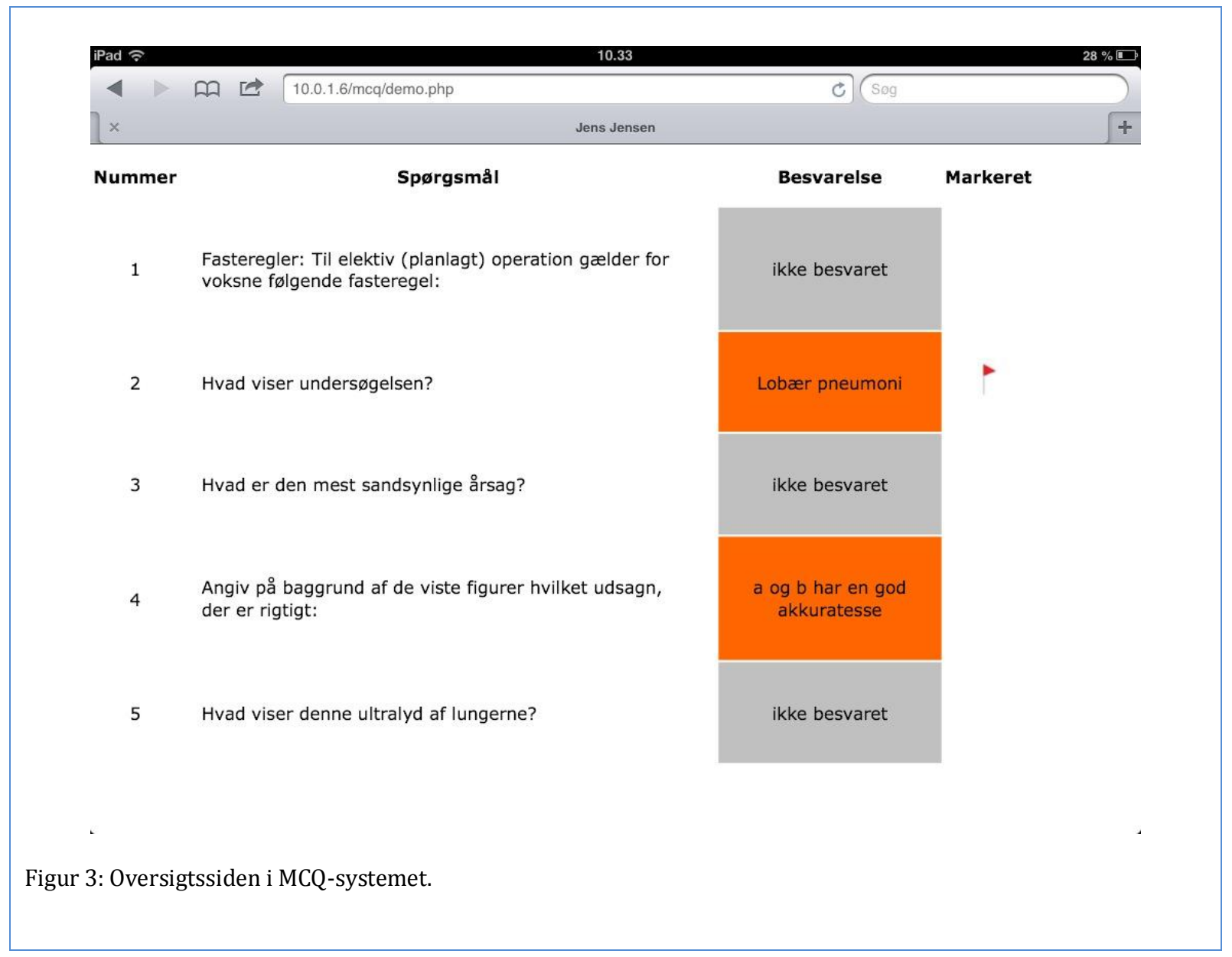

Alle svarene bliver løbende gemt i databasen med et timestamp for, hvornår besvarelsen blev lavet. Eventuelle ændringer vil også blive registreret, og hvis den studerende svarer to gange på et spørgsmål, vil begge svar være gemt som to separate rækker i eksamenstabellen indeholdende hvert sit svar og hvert sit timestamp. Dette gør det bagefter muligt at analysere, hvordan de studerende vælger at bruge tiden til eksamen, og hvor vidt det kan betale sig for dem at ændre mening.

\section{Setup}

Systemets setup baserer sig på et client-server setup, hvor en central webserver servicerer en række klienter - her i form af iPads. På webserveren ligger MCQ-systemet, og de forskellige klienter tilgår systemet, som de ville tilgå enhver anden hjemmeside. Forbindelsen sker 
via et dedikeret WiFi-netværk, som kun servicerer MCQ-systemet. Besvarelserne fra de studerende bliver løbende gemt i databasen.

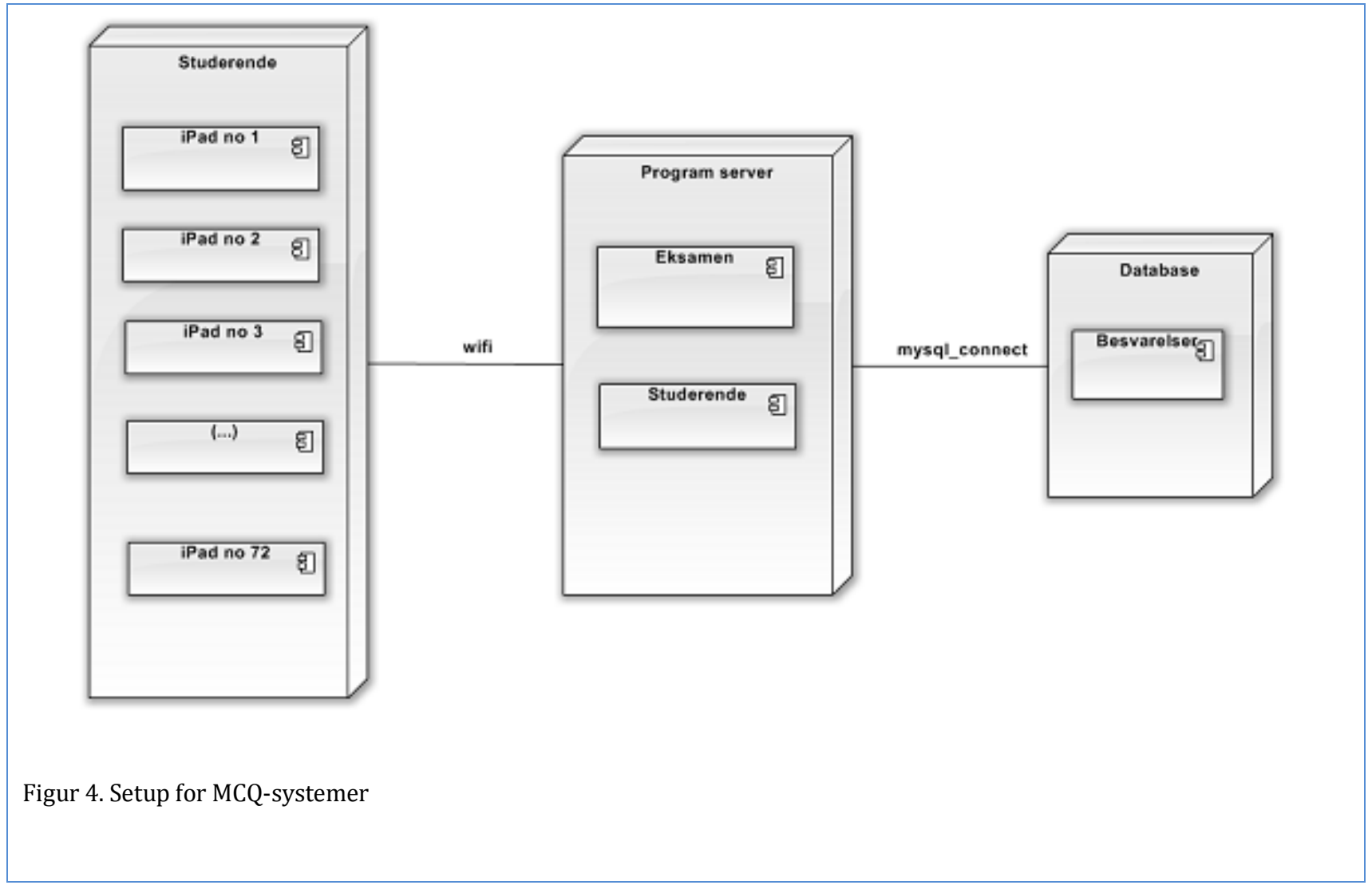

\section{Apple Configurator}

For at sikre sig mod eksamenssnyd er der behov for, at de iPads som bliver udleveret bliver konfigureret sådan, at en række funktionaliteter, så som email og deling af billeder via Photostream, er slået fra. Selve netværksopsætningen, med tilhørende adgangskontrol, er også prækonfigureret, sådan at adgangskoden til netværket ikke er kendt af andre end dem, som klargør systemet. Ved at bruge Apple Configurator (Mac App Store - Apple Configurator, 2012) er det muligt at lave en standardopsætning, som så kan uddelegeres til de forskellige iPads. Apple Configurator koster ikke noget og kan frit downloades i App Store. 


\section{Eksamensafvikling}

Eksamen blev afholdt medio 2012. Fra prodekanens side blev der taget en beslutning om, at det skulle være frivilligt for de studerende, om de ville tage eksamen digitalt eller på papir. Beslutningen skal ses i lyset af, at der var iPads til rådighed til alle studerende, og hvis alle skulle tage eksamen digitalt med den aktuelle kapacitet, ville man være nødt til at lade de studerende tage eksamen i tre hold og tilbageholde de resterende studerende i ekstra tid for at sikre sig, at de ikke informerede nogen medstuderende om eksamensindholdet.

\section{Inden eksamen}

Den primære arbejdsopgave ved afholdelse af en denne form for digital eksamen ligger inden selve eksamenen.

\section{Indtastning af MCQ-spørgsmål}

Den største opgave ved enhver eksamen, er selve oprettelsen af eksamensspørgsmål. Dette arbejde blev varetaget af det akademiske personale med forstand på emnet (Lowe, 1991), og derfor ligger denne del uden for rammerne af denne artikel.

Eksamensspørgsmålene blev modtaget via mail. Alle spørgsmål skulle indtastes manuelt i systemet sammen med svarmuligheder samt nogle kontroloplysninger. Dette arbejde varede 1-2 dage, hvorefter selve eksamenen bestående af 80 spørgsmål blev oprettet. Disse 80 spørgsmål blev lagt i vilkårlig rækkefølge. Svarmulighederne til hvert enkelt spørgsmål blev ligeledes randomiseret.

Fra Studieadministrationen blev der udfærdiget lister med alle tilmeldte til eksamen. De studerende, som skulle til den digitale eksamen, blev oprettet manuelt i MCQ-systemet. Som brugernavn kunne de studerende enten vælge at anvende deres studie- eller eksamensnummer. Adgangskoden blev genereret til dem af systemet. Oplysningerne om, hvordan de skulle tilgå systemet, blev udskrevet ud på et ark papir, sådan at det kunne omdeles sammen med iPads til selve eksamenen.

\section{Hardware}

Den anvendte server var en Mac Mini opsat som en webserver, hvor MCQsystemet blev indlagt som en almindelig hjemmeside. Denne server fik tildelt en statisk IP-adresse på netværket.

Netværket bestod af en Airport Extreme Base Station, som gav trådløs dækning i hele rummet, hvor eksamenen blev afviklet. Netværket var krypteret med WAP2-kryptering, og klienterne kommunikerede trådløst med serveren via netværket. Det var ikke muligt for klienterne at kommunikere internt med hinanden. 
Alle iPads, som skulle anvendes til eksamenen, skulle oprettes og superviseres ved hjælp af Apple Configurator. Der blev oprettet en MCQprofil, som var meget restriktiv, idet det kun var ønsket, at den studerende kunne anvende netværket til at tilgå webserveren. Anden funktionalitet så som kamera og installering af Apps blev slået fra. Disse iPads blev også sat til at anvende det netværk og den kryptering, som var oprettet på MCQsystemets router.

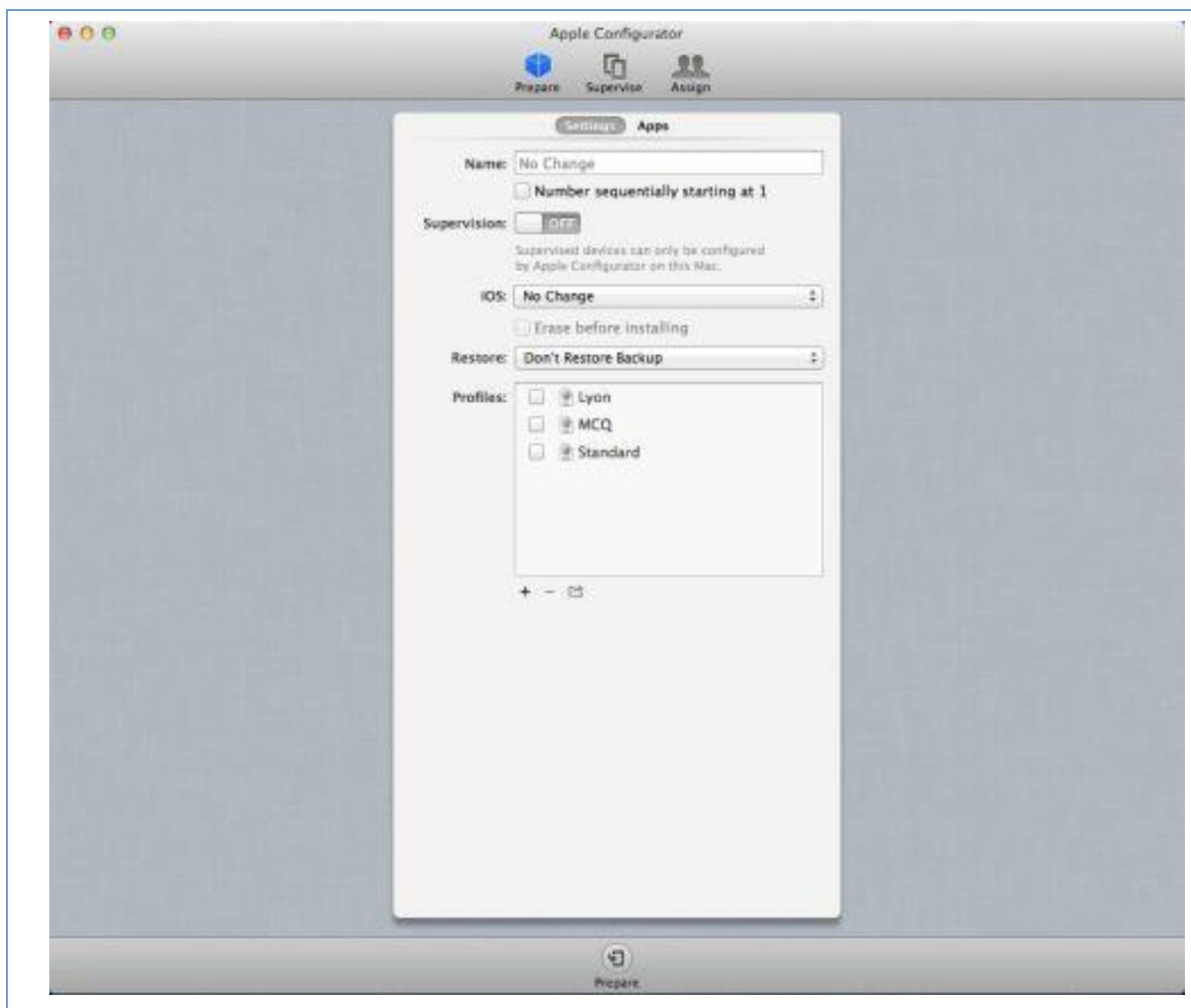

Figur 5. Apple Configurator

For at sikre systemet mod nedbrud var der backup af hardware i form af to servere, to routere og ekstra iPads, hvis noget skulle gå galt.

\section{Infomøde}

I alt var der 27 studerende, der ønskede at anvende vores iPad-system. De studerende, der havde valgt den digitale eksamen, blev indbudt til et infomøde en uge inden eksamen, hvor selve systemet blev præsenteret og 
eventuelle bekymringer besvaret. Efter disse møder steg tilmeldingerne til den digitale eksamen lidt.

\section{Selve eksamenen}

En time inden eksamensstart blev systemet sat op og testet. Så snart alle studerende, der havde tilmeldt sig den digitale eksamen, havde indfundet sig, blev de informeret om de sidste ændringer, og om hvordan de skulle bruge systemet. Et kvarter inden eksamensstart fik de udleveret en iPad sammen med deres loginoplysninger. De fik endvidere lov til at logge på selve systemet for at tjekke deres brugeroplysninger. Derved kunne det også blive kontrolleret, om alle klienter kunne tilgå systemet.

Klokken ni gav den eksamensansvarlige besked til eksamensvagterne om at dele eksamensopgaverne rundt. Samtidig gik den digitale eksamen i gang. Konkret skete dette ved, at et link blev synligt på den side, som de studerende havde logget på. Dette link bragte dem videre til det første spørgsmål i eksamenssættet. Linket blev aktiveret af en administrator ved at sende en besked fra sin iPhone til serveren. Mens de studerende gik igennem eksamenssættet og besvarede spørgsmålene, kunne forløbet følges og evt. problemer løses "on the fly". Der var ikke nogle større problemer, så tiden blev brugt til at se på svarene, mens de kom ind på serveren.

\section{Efter eksamen}

Lige så snart eksamen var forbi, blev der lavet backup af databasen, som blev gemt på en ekstern harddisk, hvorefter de udleverende iPads blev indsamlet. Udregningen af antal rigtige besvarelser skete ved hjælp af en forudprogrammeret funktion i systemet, og resultatet blev afleveret til den eksamensansvarlige, som havde til opgave at indtaste den endelige karakter i det studieadministrative system. Eftersom det var første gang at den digitale eksamen blev afviklet, blev det kontrolleret, at systemet havde talt rigtigt sammen, ved at der blev lavet en manuel optælling af besvarelserne i stil med den, man laver til en papir-baseret eksamen. Første gennemtælling viste nogle uoverensstemmelser med de udregninger, som systemet nåede frem til. Disse skyldtes dog fejl i den manuelle sammentælling og havde ikke noget med systemets udregninger at gøre. Dette var således med til at bekræfte usikkerheden ved manuel optælling.

Lige efter den afholdte eksamen blev de studerende bedt om at svare på et evalueringsskema. Ved eksamen i "Inflammation" var der 18 ud af 173 (10\%) af de studerende, som valgte at benytte den digitale eksamensform. Af disse udfyldte 14 evalueringsskemaet. 
svar:

\begin{tabular}{|l|c|c|c|c|}
\hline & Ja & Nej & Både / og & Ved ikke \\
\hline Syntes du eksamenssystemet på iPads var stabilt? & 13 & & 1 & \\
\hline $\begin{array}{l}\text { Syntes du eksamenssystemet på iPads var } \\
\text { brugervenligt? }\end{array}$ & 13 & & 1 & 1 \\
\hline Var det bedre med iPads end papir? & 12 & & 1 & 1 \\
\hline $\begin{array}{l}\text { Vil du vælge at bruge iPad systemet til en anden MCQ } \\
\text { eksamen? }\end{array}$ & 14 & & & \\
\hline Vil du anbefale iPad systemet til andre? & 14 & & & \\
\hline
\end{tabular}

For "Abdomen"-eksamen var det 9 ud af 140 (6\%) studerende, der valgte muligheden for at tage eksamen ved brug af iPads. Af disse besvarede 7 evalueringsskemaet.

Spørgsmål

svar:

\begin{tabular}{|c|c|c|c|c|}
\hline & $\mathrm{Ja}$ & Nej & Både / og & Ved ikke \\
\hline Syntes du eksamenssystemet på iPads var stabilt? & 7 & & & \\
\hline $\begin{array}{l}\text { Syntes du eksamenssystemet på iPads var } \\
\text { brugervenligt? }\end{array}$ & 7 & & & \\
\hline Var det bedre med iPads end papir? & 7 & & & \\
\hline $\begin{array}{l}\text { Vil du vælge at bruge iPad systemet til en anden MCQ- } \\
\text { eksamen? }\end{array}$ & 7 & & & \\
\hline Vil du anbefale iPad systemet til andre? & 7 & & & \\
\hline
\end{tabular}

Resultat af denne evaluering viste en stor tilfredshed med denne form for digitalisering af eksamen (se tabel \#\#).

At ikke flere valgte at tage eksamen på den digitale form skyldtes formentlig usikkerhed ved brug af teknologien, når de studerende indtil nu kun har været bekendt med MCQ-eksamen på papir. 
På evalueringsskemaet havde de studerende mulighed for at komme med yderligere kommentarer. Generelt var kommentarerne positive. Den øvrige feedback var konstruktiv og vil medvirke til den videre udvikling af den digitale MCQ-eksamen.

Udpluk af de studerendes kommentarer ses herunder:

"Selvom jeg ikke var til informationsmødet, var det nemt at gå til på selve dagen!:) Følte mig på intet tidspunkt utryg, vidste at I var der til at guide og informere, hvis der opstod problemer, men det gjorde der jo ikke! Det fungerer så fint, dejligt tilgængeligt, dejligt lige til og tror det sparer tid! især oversigt og flagfunktion er tidsbesparende tror jeg! God sommer;)"

"Kunne være rart hvis man kunne sende ens egen besvarelse til sig selv, så man efterfølgende selv kan tjekke op på ens svar ved hjælp af de udleverede papir, især hvis der har været nået man har været usikker på."

"Det kunne være super lækkert, hvis der var mulighed for at sætte flere former for markeringer. Fx en gul og en rød mærkat! Ellers var det nemt og overskueligt. Det var i øvrigt første gang jeg sad med en iPad i mere end to min."

"Det var meget mere overskueligt, og tidsbesparende med iPad. Flagsystemet fungerede super godt for mig, for på den måde slap man for at sætte blyantstegn og bladre frem og tilbage i sine papirer for at finde de ønskede spørgsmål. Desuden var det utroligt brugervenligt, selv for en, der aldrig har haft en iPad i hånden før igår aftes! Ville vælge det igen til hver en tid."

Uformelt blev nogle studerende spurgt, hvorfor de ikke havde valgt at bruge det digitale system. Deres tilbagemeldinger gik mest på, at de enten ikke havde hørt om muligheden, eller at de ikke følte sig helt sikre på systemet. Disse oplysninger er dog ikke yderligere valideret.

\section{Problemer}

Der var nogle mindre problemer ved selve afholdelsen af eksamen. Den første eksamen, der blev afholdt, var i "Inflammation", hvor 18 studerende havde valgt den digitale eksamen. Ud af disse 18 var der én, som skulle have ekstra tid til besvarelsen af opgaven. Denne person blev placeret lidt væk fra de andre, sådan at eksamensvagterne lettere kunne overskue, 
hvem der havde fået ekstra tid. Dette medførte, at vedkommende gik glip af den introduktion, som de øvrige studerende fik inden eksamensstart.

Til denne eksamen var der, efter de studerendes ønsker, udviklet en funktionalitet, som gjorde det muligt at markere et spørgsmål for at vende tilbage til det ved en senere lejlighed. Denne funktionalitet blev lavet efter infomødet, hvilket var en uge inden eksamensstart, og var derfor ikke gennemtestet så grundigt, som man kunne have ønsket. Således var det kendt, at hvis spørgsmålene blev markeret i en bestemt rækkefølge, så var der en risiko for, at markeringen ikke blev registreret. På trods af forklaringer til de studerende omkring den korrekte rækkefølge, så voldte denne mangel en smule frustrationer hos de studerende under selve eksamenen. Ved den efterfølgende eksamen i "Abdomen" var denne fejl blevet rettet, sådan at disse frustrationer ikke gentog sig.

Ved den første eksamen var der nogle uoverensstemmelser blandt svarmulighederne i henholdsvis den digitale udgave og papirudgaven. Disse uoverensstemmelser bestod i, at rækkefølge på svarmulighederne ikke var helt ens ved alle spørgsmålene. Eftersom de studerende, der tog eksamenen digitalt, også fik udleveret papirudgaven, så var der nogle studerende, der brugte tid på at konstatere, at der fandtes en uoverensstemmelse i rækkefølgen af svarmuligheder imellem de to eksamener. Dette afstedkom nogle bekymringer hos de studerende og efter eksamenen var der en del mailkorrespondance mellem de studerende og den ansvarlige for det faglige indhold af eksamenen. Årsagen til denne uoverensstemmelsen skal findes $i$, at papirudgaven blev lavet inden den digitale. Da den digitale eksamen blev oprettet, blev den manuelt tilpasset til at ligne papirudgaven. Dog var det kun det rigtige svar i begge udgaver, der stemte overens. De to forkerte svarmuligheder kunne derfor være ombyttet i henholdsvis den digitale version og papirversionen. Begrundelsen for bekymringen skal findes i det retteark, som bliver anvendt for at tælle antal rigtige besvarelser til en MCQ-eksamen i papirform. 

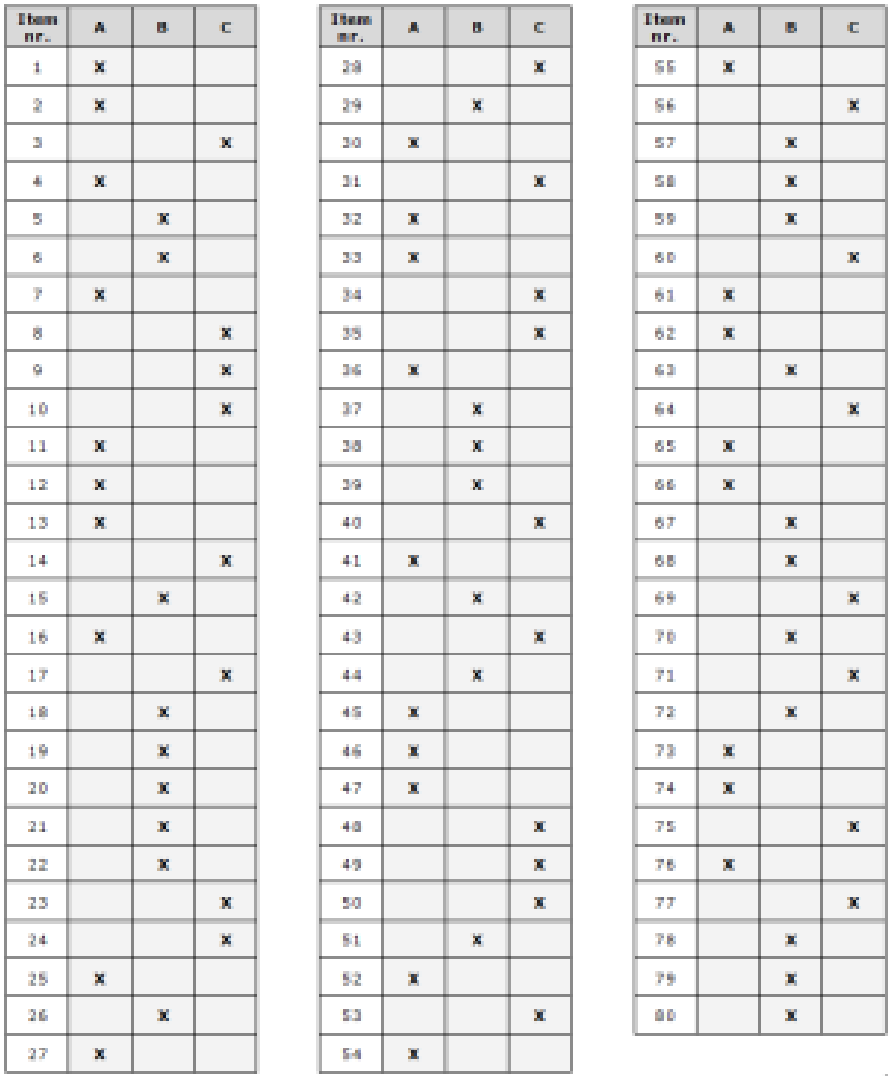

Dette retteark viser de korrekte besvarelser til en MCQ-eksamen.

Rettearket er printet på en transparent og bliver lagt over alle de svarark, som de studerende har indleveret. Antal korrekte besvarelser kan findes med afsæt i de afkrydsede felter. Hvis den studerende har besvaret spørgsmål 9 ovenover ved at afkrydse A, så vil der være to krydser ud foran spørgsmål 9 - A som er forkert, og C som er det korrekte svar - og dette vil indikere, at den studerende har besvaret spørgsmålet forkert. Hvis den studerende havde svaret $C$ til spørgsmål 9 , så ville krydset i transparenten ligge over krydset på det papirark, som den studerende havde indleveret, og dermed indikeret et korrekt svar.

Så, til en MCQ-eksamen på papir ved de studerende, at det rigtige svar afhænger af, hvorhenne man sætter sit kryds. Til den digitale udgave af samme eksamen lægges der ikke vægt på, hvorhenne det rigtige svar er placeret på skærmen. Det er derimod indholdet af det afgivne svar, der holdes op imod det rigtige svar i databasen. For et program tager en sammenligning næsten ingen tid, mens det for en person tager uforholdsmæssig lang tid at skulle lave denne sammenligning 80 gange, især fordi svarmulighederne ofte afviger meget lidt fra hinanden i ordlyden. De studerende var ikke klar over, at den digitale udgave talte antal rigtige svar efter en anden procedure end normalt, og derfor var det med god grund at de kontaktede den eksamensansvarlige med deres bekymringer. 
Til den næste eksamen blev der skabt overensstemmelse mellem papirudgaven og den digitale udgave, sådan at de studerende ikke skulle bekymre sig unødvendigt. Denne eksamen blev afholdt i et mindre lokale, hvor bordene stod meget tæt sammen. To af de studerende sad kun ca. en meter fra routeren. Da eksamen var i gang, opstod der med få minutters mellemrum det problem, at disse to studerende blev smidt af netværket. Problemet opstod sandsynligvis pga. den korte afstand mellem router og iPads. De kunne dog uden videre logge på igen og fortsætte eksamenen, hvor de var kommet til.

\section{Hvad har vi lært?}

Udover de problemer, som blev nævnt i forrige afsnit, har vi lært en del af selve forløbet og hele den organisatoriske struktur omkring en digital eksamen. Overordnet set har de to eksamener i "Inflammation" og "Abdomen" fungeret som en slags pilottest for systemet. Antallet af dem, der valgte at tage eksamenen digitalt svarede nogenlunde til $5 \%$ af de eksamenstilmeldte.

\section{Udvikling}

Systemet blev udviklet med udgangspunkt i en standard Apache-MySQLPHP-løsning. Dette valg blev gjort for at sikre, at systemet kunne afvikles på så mange uafhængige platforme som muligt. Selvom den valgte udviklingsløsning er standard, så er der alligevel nogle små forskelle i opsætningen af Apache-MySQL-PHP på de forskellige operativ systemer. Den lille forskel, der voldte os mest hovedbrud var, at MacOS kører PHPdelen med Xcache (XCache, 2012) som standard. Xcache er en opcoded cacher, som gemmer resultatet af den kompilerede PHP kode, sådan at man slipper for at re-kompilere PHP-koden. Forklaret på en anden måde, så er webserveren $n ø d t$ til at fortolke vores PHP-kode for at vide, hvad den skal gøre. Denne fortolkning tager tid, og en opcoded cacher som Xcache er med til at nedsætte dette tidsforbrug ved at huske dele af koden, som allerede er blevet fortolket. Hvis dele af koden anvendes meget, kan udførelsestiden nedsættes betydeligt ved anvendelse af en opcoded cacher.

\section{Organisatorisk}

Samarbejdet mellem de involverede parter under udvikling og afvikling af MCQ-systemet har fungeret godt. Selve studieadministrationen fik et nyt administrativt system (STATA), mens selve udviklingsforløbet var i gang, hvilket dog ikke var en kilde til problemer.

\section{Udarbejdelse af eksamen}

Enhver eksamen har en eksamensansvarlig, som skal sørge for, at eksamenen bliver oprettet. Til udarbejdelse af en MCQ-eksamen skal der oprettes 160 spørgsmål, sådan at man har nok spørgsmål til både en eksamen og en reeksamen. Disse spørgsmål blev sendt til den eksamensansvarlige, som så sendte dem videre til dem, som skulle oprette 
den digitale eksamen. Dette blev gjort i god tid inden afholdelse af eksamen.

Det viste sig, at der i tidsrummet efter oprettelsen af spørgsmålene digitalt og at de blev sendt til trykkeriet blev foretaget nogle små justeringer $\mathrm{i}$ enkelte eksamensspørgsmål i papirudgaven, som ikke blev kommunikeret videre. Disse ændringer blev opfanget og justeret i tide i den digitale udgave. Så længe man vælger at afvikle både en papir- og en digital udgave af en eksamen er det således vigtigt, at spørgsmål og eksamenssæt kun bliver oprettet og justeret et centralt sted.

I fremtiden kunne man overveje, om det ikke kunne betale sig at oprette selve eksamenssættet online, i stedet for som nu, hvor hvert enkelt spørgsmål bliver oprettet i en Microsoft Word skabelon, som derefter overføres manuelt til eksamenssystemet. Alle spørgsmålene skal alligevel indtastes i en database, uanset om de skal bruges til en papir- eller digital eksamen.

Hvis spørgsmålene oprettes online, ville en sådan løsning give andre fordele, hvor den mest oplagte fordel ville være, at alle felter i Microsoft Word-skabelonen blev udfyldt korrekt. Under halvdelen af de anvendte Word-skabeloner var udfyldt tilfredsstillende. En anden fordel ville være, at de møder, som den eksamensansvarlige holder med censorerne, kunne afholdes online med en videokonference, hvor alle parter havde adgang til samme online version af eksamenssættet.

\section{Infomøde}

Det infomøde, som blev afholdt, var lagt én uge inden selve eksamen. På dette møde blev de bekymringer, som de studerende havde, afklaret. Tidsrummet frem til eksamen var for kort til, at mange flere meldte sig til den digitale eksamensform. Til en anden gang kunne man med fordel lægge dette infomøde tidligere i forløbet, sådan at de studerende havde god tid til at overveje og vælge den digitale løsning så længe, der fortsat er et valg.

\section{Eksamensvagter}

Til selve eksamen er det eksamensvagterne, der kontrollerer begivenhederne efter nogle bestemte retningslinjer. Disse retningslinjer er udarbejdet til at facilitere en skriftlig eksamen på papir. I disse retningslinjer står der blandt andet, at de studerende skal have udleveret et eksemplar af eksamenssættet. For de studerende, der tog eksamen digitalt, var dette overflødigt, da de havde eksamenssættet digitalt. Det skabte derfor lidt forvirring, når de sad med to eksamenssæt. Man kunne overveje at ændre eksamensvejledningen, således at den bliver tidssvarende og tager højde for digitale medier.

\section{Fremtiden}


Der er allerede planlagt flere digitale MCQ-eksamener på Health. Disse vil blive afholdt januar 2013, og allerede nu er deltagerantallet knap 50. Dette medfører, at det eksisterende system fortsat udvikles og forbedres sammen med de procedurer, der knytter sig til en digital eksamen, således at man snarest kan overgå til en ren digital eksamensafholdelse i alle henseender.

\section{Konklusion}

Den digitale løsning på afvikling af MCQ-eksamen, som nu benyttes på Faculty of Health, Aarhus Universitet, har i sin udvikling og opsætning vist sig at imødekomme de administrative udfordringer, som non-digitale eksamener af denne type står overfor, så som optælling og udregning af karakterer samt den statistiske analyse af eksamensspørgsmål og besvarelser med henblik på kvalitetssikring af eksamen og til dels undervisningen.

Vores erfaring med det valgte hardwareløsning har været positiv. Mobiliteten og datasikkerheden, som denne løsning hardware og softwaremæssigt giver, har mødt de krav, som afholdelsen af en eksamen af denne type har i lyset af de logistiske udfordringer, der følger med at afvikle en eksamen for mellem 20 og 200 studerende i variable lokaliteter.

De fortsatte udfordringer bliver at udvikle eksamensspørgsmål, der til fulde udnytter mulighederne som den heri beskrevne eller tilsvarende digitale løsninger tilbyder i form af billede, video og lyd, således, at det digitale potentiale ikke kun udnyttes administrativ men også rent eksamenteknisk.

\section{Referencer}

Attewell, J. (2005). From Research and Development to Mobile Learning : Tools for Education and Training Providers and their Learners.

Bygningsstyrelsen, U.- og. (2010). Rapport om digitale eksaminer på universiteterne - Styrelsen for Universiteter og Internationalisering. Universitets- og Bygningsstyrelsen. Retrieved from http://www.ubst.dk/publikationer

Ellaway, R., \& Masters, K. (2008). AMEE Guide 32: e-Learning in medical education Part 1: Learning, teaching and assessment. Medical teacher, 30(5), 455-73. doi:10.1080/01421590802108331

Herrmann, A. (2012). uRespond: A Classroom Response System on the iPad.

Hwang, G.-J., \& Chang, H.-F. (2011). A formative assessment-based mobile learning approach to improving the learning attitudes and achievements of students. Computers \& Education, 56(4), 1023-1031. doi:10.1016/j.compedu.2010.12.002

III, V. R. (2007). Mulighedernes samfund, (November). Retrieved from http://www.stm.dk/publikationer/Regeringsgrundlag2007/index.htm 
Jalali, B. A., Trottier, D., \& Tremblay, M. (2012). Administering a Gross Anatomy Exam Using Mobile Technology How one medical school made the switch from paper to paperless . elearn Magazine : Administering a Gross Anatomy Exam Using Mobil ..., 10-13.

Jones, J. L., \& Sinclair, B. (2011). Assessment on the Go : Surveying Students With an iPad.

Lowe, D. (1991). How To Do It Set a multiple choice question ( MCQ ) examination, 302(March), 780-782.

MAMP: Mac, Apache, MySQL, PHP. (2012). Retrieved September 3, 2012, from http://www.mamp.info/en/index.html

Mac App Store - Apple Configurator. (2012). Retrieved September 3, 2012, from http://itunes.apple.com/dk/app/appleconfigurator/id434433123?mt=12

McNulty, J., \& Chandrasekhar, A. (2011). Computer-Based Testing in the Medical Curriculum: A Decade of Experiences at One School. Journal of Educational ..., 45(3), 287-295. Retrieved from http://baywood.metapress.com/index/F62Q733815L33703.pdf

Mowla, M. J., Zaman, M. S., Chowdhury, M. M., \& Abdal, S. N. (2007). Electronic MCQ answering system for classroom e-learning and examination. 2007 10th International Conference on Computer and Information Technology, 1-5. doi:10.1109/ICCITECHN.2007.4579403

MySQL :: The world's most popular open source database. (2012). Retrieved September 3, 2012, from http://www.mysql.com/

OSCEhome Cinical Skills Assessment Medical OSCE Exam Objective Structured Clinical Examination. (2012). Retrieved September 3, 2012, from http://www.oscehome.com/

PHP: Hypertext Preprocessor. (2012). Retrieved September 3, 2012, from http://www.php.net/

Vyas, R., \& Supe, A. (2008). Multiple choice questions: A literature review on the optimal number of options. THE NATIONAL MEDICAL JOURNAL OF INDIA, 21(3), 130-133.

Wang, T.-H. (2008). Web-based quiz-game-like formative assessment: Development and evaluation. Computers \& Education, 51(3), 12471263. doi:10.1016/j.compedu.2007.11.011

Welcome to The Apache Software Foundation! (2012). Retrieved September 3, 2012, from http://www.apache.org/

XCache. (2012). Retrieved September 3, 2012, from http://xcache.lighttpd.net/

Økonomistyrelsen. (2011). DEN DIGITALE VEJ TIL FREMTIDENS VELFÆRD. Rosendahls - Schultz Distribution. Retrieved from www.fm.dk, www.kl.dk, www.regioner.dk 